\title{
MANGANESE AND SULFUR REDUCTION BY SOIL FUNGI ON POST-COAL MINING AREAS AT KUTAI KARTANEGARA, EAST KALIMANTAN
}

\author{
BAYU WIDHAYASA ${ }^{1}$, SUDRAJAT ${ }^{2}$, RUSDIANSYAH ${ }^{3}$ \\ ${ }^{1}$ Environmental Sciences Master's Degree, Mulawarman University. Jl. Ki Hajar Dewantara, Gunung Kelua, Samarinda. \\ ${ }^{2}$ Faculty of Mathematics and Natural Sciences, Mulawarman University. J. Barong Tongkok, Gunung Kelua, Samarinda. \\ ${ }^{3}$ Faculty of Agriculture, Mulawarman University. Jl. Pasir Belengkong Gunung Kelua, Samarinda.
}

Corresponding author: bwidhayasa@gmail.com

\begin{abstract}
At such levels, manganese and sulfur can damage ecosystems and water distribution systems and causes serious problems to surrounding water-soil bodies in the post-coal mining areas. Soil fungal has a positive contribution to the improvement of soil physical and chemical properties. This research aims to determine the population size and diversity of soil fungi related to the manganese and sulfur concentrations at various stages of reclamation in East Kalimantan. The numbers of soil fungi increased in the year after reclamation and then decreased after aging for nine years. Aspergillus, Penicillium, Cephalosporium, Gliocladium, Humicola, Trichoderma, and Paecilomyces, were among the fungi found colonizing in the soil of the reclamation areas. The numbers of soil fungi were found negatively correlated with manganese concentrations. A negative correlation found between the numbers of soil fungi and sulfur concentrations. The slightly higher number of soil fungi in the reclamation areas can be attributed to lower manganese and sulfur concentrations.
\end{abstract}

Keywords: Soil fungi, reclamation, manganese, sulfur, reduction

\section{INTRODUCTION}

Coal is the most abundant fossil fuel on the earth and supplies about $75 \%$ of the total fuel resources (Sahoo et al., 2016; Dutta et al. 2017). In Indonesia, which is known for its big variety of resources, the extraction and export of coal have been expanded remarkably over recent years, leading to the country's current standing as the world's largest exporter of coal by weight. According to Funfgeld (2016) in the major coal producing areas of East Kalimantan, South Kalimantan, and South Sumatera. Almost all coal mines in Indonesia use the open pit system (Yusuf and Arisoesilaningsih, 2017), the system converts the landform and affects the biotic components (plants, animals), abiotic components (physical, chemical), and societal change. Due to land conversion, the decrease of land productivity, the reduced environmental quality, and contamination of water and soil. This is especially the case in East Kalimantan, where mining concessions cover nearly three-quarters of the total municipal area.

Komara et al. (2016) stated that considering the impact of mining on the environment, postmining sites need to be rehabilitated by conducting reclamation and revegetation. Indonesia law requires mining companies to fill in pits that are no longer in use, and re-vegetate and restore mining sites (Funfgeld, 2016). The longterm goal of this activity is to improve the condition of the microclimate, biodiversity, wildlife habitats, and improve the condition of the land to be more protective, conservative and productive (Mummey et al., 2002; Yusuf and Arisoesilaningsih, 2017). However, coal mining activities are unavoidably linked with the excavation of huge amounts of dump rocks, which are of great environmental concern due to the potential for production of acidic and metal-rich drainage (Wong, 2003; Qin et al., 2016). At reclamation site, soil nutrients are generally limited, soil $\mathrm{pH}$ is low, and there are often metal 
contaminants. A large volume of overburden materials accumulated during the mining of coal is subsequently exposed to the environment. This leads to major ecological and environmental degradation especially when the materials contain manganese and sulfur. Abandoned mines often contain elevated concentrations of dissolved manganese and sulfur (Silva et al., 2011; Chaput et al., 2015). At such levels, manganese and sulfur can damage ecosystems and water distribution systems and causes serious problems to surrounding water-soil bodies.

Soil microbes are vital for the continuous cycling of nutrient and for driving aboveground ecosystems. It is important to study microbial diversity not only for basic scientific research but also to understand the link between diversity and community structure and function (Meliani et al., 2012). The presence of soil microbes can increase the ability to return to the natural conditions of a degraded land ecosystem due to coal mining activities (Birch et al., 1991). Fungi and bacteria are the two groups that dominate the microbial decomposer community, and crudely defined, they share the function of decomposing organic matter in the soil, indicating that there is a strong potential for interaction (Rousk et al. 2009). Soil fungal population has a positive contribution to the improvement of soil physical and chemical properties (Detheridge et al., 2016). Frezquez et al. (1987) noted that several investigators have used soil fungal population estimates, and particularly fungal diversity and community composition responses, to gain a better understanding of ecosystem functioning and development on post-coal mining sites.

The composition of soil fungi is related to the soil chemical properties, as well as to the type of vegetative cover during succession. In this study, an attempt was made to determining the population size and diversity of soil fungi related to the manganese and sulfur concentrations at various stages of reclamation in East Kalimantan.

\section{MATERIALS AND METHODS}

\section{Study area}

This study was conducted using a series of reclamation stages that are situated on surface coal mines located in the concessions cover of PT Kitadin Site Embalut in Kutai Kartanegara, East Kalimantan. The minimum and maximum daily temperatures of 27 to $35^{\circ} \mathrm{C}$, the mean monthly humidity $91 \%$ and the mean monthly precipitation was $176.2 \mathrm{~mm}$. Laboratory analysis conducted in the Soil Science Laboratory of Tropical Rain Forest Research Center, and Plant Protection Laboratory of Agriculture Faculty of Mulawarman University. Purposive sampling was used to take the sample in a research location which represented the condition of every location. The reclamation areas varied in age, soil characteristics, vegetation, and type of post-mining revegetation treatment.

\section{Procedures}

The soil of the field plots was sampled at six different stages of reclamation areas (Figure 1). For each stage of reclamation area made three plots of $10 \mathrm{~m} \times 10 \mathrm{~m}$. Coordinate points were determined using GPS, then measuring the following: numbers of soil fungi and soil chemical properties (manganese and sulfur concentrations).

\section{Soil sampling}

Soil sampling was conducted in all research plots with drill ground at a depth of $0-30 \mathrm{~cm}$. On each plot was take five-point drilling, soil samples composited for each plot. Composite soil samples were then taken $500 \mathrm{~g}$ of each class of depth, put into plastic bags, labeled and transported to the laboratory. The numbers of soil fungi determined from fresh soil samples. Soil physicochemical properties determined from air-dried soil samples.

\section{The numbers of soil fungi}

The numbers of soil fungi were estimated by using dilution plate technique in Potato Dextrose Agar which contains $1 \mathrm{mg} \mathrm{ml}^{-1}$ and incubated at $30{ }^{\circ} \mathrm{C}$ to 4 days. Soil samples were serially diluted and plated on potato dextrose agar. Soil samples ( $1 \mathrm{~g}$ ) were added to $10 \mathrm{ml}$ of sterilized distilled water and shaken for $15 \mathrm{~min}$. The original suspension (1 $\mathrm{ml}$ ) diluted in $9 \mathrm{ml}$ of sterilized distilled water. This process was repeated three times to obtain a 10fold dilution series. Each soil suspension spread in triplicate series. Data from triplicate readings were expressed as Colony Forming Unit (CFU) $\mathrm{g}^{-1}$ dry soil. The fungal isolates were identified to the genus level and in some cases species level, using standard keys of morphological features (Barnett and Hunter, 1972; Domsch et al., 1980). The relative abundance of the most frequent fungal genera determined by calculating the proportion of each genus in relation to the total number of isolates. 


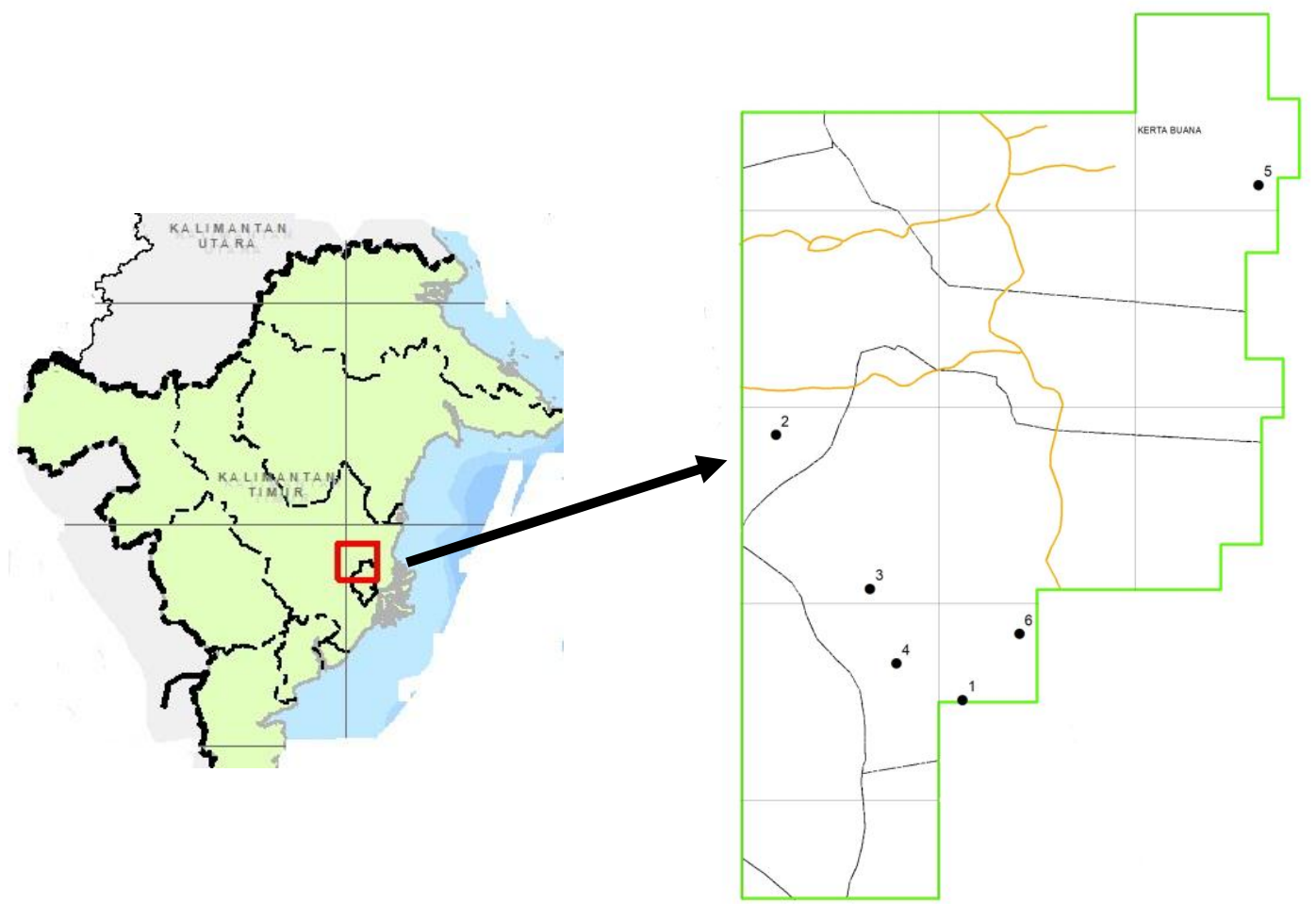

Figure 1. Location of the study area in East Kalimantan, black circles are reclamation areas.

\section{Soil chemical properties}

The soil sample was taken from the depth of 0 $30 \mathrm{~cm}$ and the results calculated after being dried in the oven with a temperature of $150{ }^{\circ} \mathrm{C}$ until constant weight reached. Manganese determines by using Atomic Absorption Spectrophotometry method and sulfur determines by using the Spectronic method.

\section{Data analysis}

Data analyzed in triplicate by using Microsoft Office Excel 2007. Pearson's correlation coefficients were conducted on the number of soil fungi and chemical properties to determine how these variables were related. All data processing the Pearson's correlation coefficients performed by using SPSS Statistics ver. 17.0.

\section{RESULTS AND DISCUSSION}

The numbers of soil fungi on the various stages of reclamation

This investigation has demonstrated that each stage of reclamation was different in terms of the numbers of soil fungi. The numbers of soil fungi increased in the year after reclamation and then decreased after aging for nine years (Figure 2). These results suggest that nine years after reclamation areas may not yet be stable, in these areas may still have adverse soil chemical and physical properties (i.e. high salts and high clay contents). The decline in numbers of soil fungi probably reflected the exhaustion of added carbon and nitrogen from the litter. Each stage had a different number of soil fungi, thus indicating that a given fungal group had a close relationship to a specific plant successional stage of vegetation.

The changes in the ecosystem structure have an impact on the composition of the soil fungal in the various stages of reclamation. Our interpretation is that the dynamics of the numbers of soil fungi observed seems to be related to changes in the availability of carbon resources occurring during degradation, and that the low numbers of soil fungi could have been due to the absence of organic matter in the form of litter (Frezquez et al., 1987; Gomez et al., 2016). We also expected that changes in the numbers of soil fungi would be strongly linked to vegetation dynamics. Our results show that the numbers of soil fungi differed appreciably from one ecological area to the others, being influenced by plant cover and especially by soil factor. Roy-Bolduc et al. (2016) found a significant correlation between plant and fungal communities, which were influenced by similar soil chemical properties. Garcia et al. (2015) reported a similar result. 
Agroradix Vol. 2 No.2 Juni (2019)

ISSN : 2621-0665

Table 1. Distribution and relative density of fungal genera in the various stages of reclamation

\begin{tabular}{|c|c|c|c|c|c|c|}
\hline \multirow{2}{*}{ Fungal groups } & \multirow{2}{*}{ Undisturbed } & \multirow{2}{*}{ Disturbed } & \multicolumn{4}{|c|}{ Years after reclamation } \\
\hline & & & 2-year & 9-year & 12-year & 16-year \\
\hline Aspergillus & 7 & 6 & 5 & 6 & 4 & 6 \\
\hline Penicillium & 1 & 0 & 1 & 1 & 0 & 1 \\
\hline Cephalosporium & 0 & 1 & 0 & 0 & 0 & 0 \\
\hline Gliocladium & 0 & 1 & 0 & 0 & 1 & 0 \\
\hline Humicola & 0 & 0 & 0 & 0 & 1 & 0 \\
\hline Trichoderma & 0 & 0 & 0 & 0 & 1 & 0 \\
\hline Paecilomyces & 0 & 0 & 1 & 0 & 0 & 0 \\
\hline \multicolumn{7}{|l|}{ Unidentified } \\
\hline Isolate No. 1 & 1 & 0 & 0 & 0 & 0 & 0 \\
\hline Isolate No. 2 & 0 & 0 & 0 & 0 & 1 & 0 \\
\hline No. of isolates & 9 & 8 & 7 & 7 & 8 & 7 \\
\hline No. of genera & 3 & 3 & 3 & 2 & 5 & 2 \\
\hline
\end{tabular}

Meliani et al. (2012) stated that the activity and species composition of microbes generally influenced by many factors including physicchemical properties of the soil, temperature, and vegetation.

The results in Table 1 show that many fungal genera isolated from the various stages of reclamation were common to all areas. In this study, the important fungal genera with respect to the number of soil fungi isolated were Aspergillus, Penicillium, Cephalosporium, Gliocladium, Humicola, Trichoderma, and Paecilomyces. They are among the fungi found colonizing in the soil and the most diverse and ecologically significant group of fungi on the rhizosphere. However, some appeared in considerably higher densities than others.

The genera with a higher dominance in the total fungi isolated, according to the number of the genus were Aspergillus (74\%), Penicillium (8\%), Gliocladium (4\%), Cephalosporium, Gliocladium, Humicola, Trichoderma, Paecilomyces, and unidentified genera (2\%). The result of this work showed that the reclaimed coal mine sites dominated by Aspergillus. Kurakov et al. (2008) reported similar fungal genus in their work and Garcia et al. (2015) established that because this genus is capable of using different substrates in the soil, they predominated over other fungal populations that used only a few specific substrates. According to Gomez et al. (2016), the reason why other fungal genera were in a low proportion or absent in the sampling sites was that saprophytic fungi present in a high relative density.

\section{Manganese and sulfur concentrations on the various stages of reclamation}

In this study, the manganese concentrations declined in the years after reclamation and then increased in the next two oldest reclamation stages (Figure 3). Considering all the reclamation stages, the youngest stage exhibited higher manganese concentrations indices than any of the reclamation stages. This study showed that nine years after reclamation had lower manganese concentrations than any of the reclamation stages.

The results in Figure 4 also show that the youngest reclamation stage had the highest concentration of sulfur than any of the reclamation stages. In contrast to the declining manganese concentrations, the concentration of sulfur generally increased with age up to the transitional stage but decreased slightly in the oldest reclamation stage.

Kutai Kartanegara district is one example of an Indonesian region affected by bituminous coal mining activities, with mines exploited since the mid-1980s. High concentrations of manganese (175.81 to $754.78 \mathrm{mg} \mathrm{kg}^{-1}$ ), and sulfur (13.09 to $39.76 \%)$ found in its soil. The results presented in Figure 3 show that the concentration of manganese in this study was higher than the results from Mulyana (2009) to the rehabilitated soil in Ciliwung (16.92 to $30.85 \mathrm{mg} \mathrm{kg}{ }^{-1}$ ). The results in Figure 4 showed a higher concentration of sulfur than the results from Marganingrum and Noviardi (2010) to the reclaimed coal mine in Berau (2.18 to $8.28 \%$ ). According to Campaner et al. (2014), the high concentration of these elements has resulted from oxidation of sulfides, 


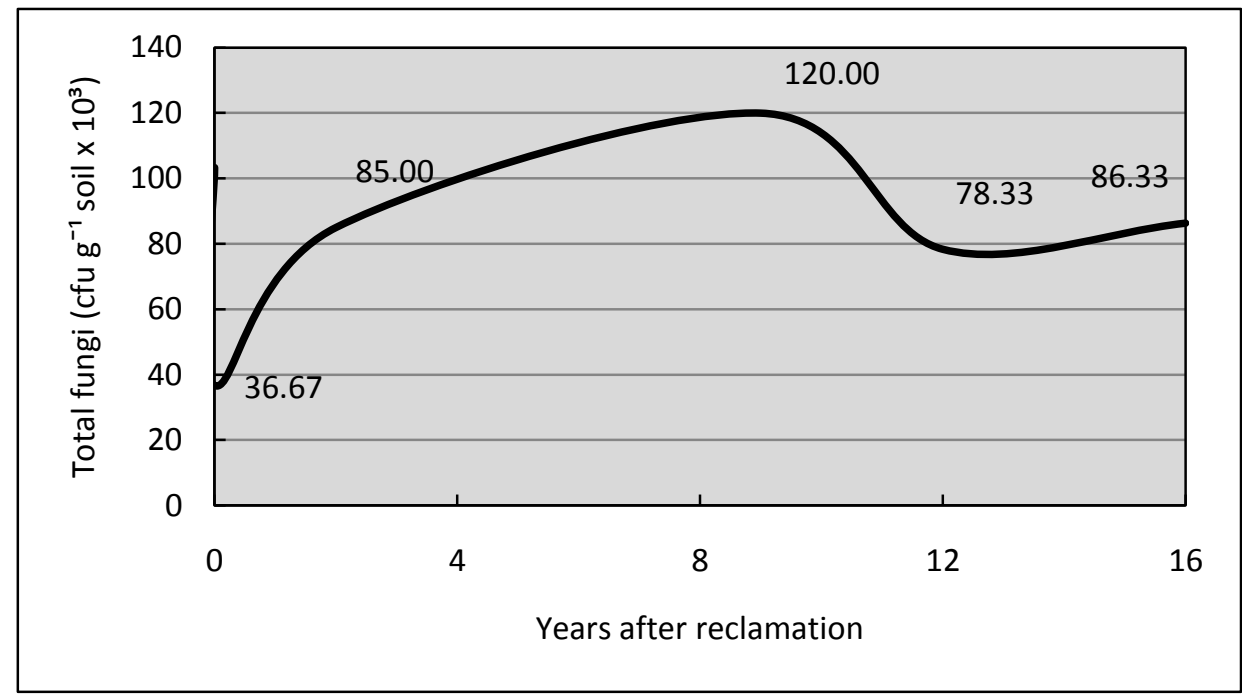

Figure 2. The dynamics of the numbers of soil fungi in the various stages of reclamation.

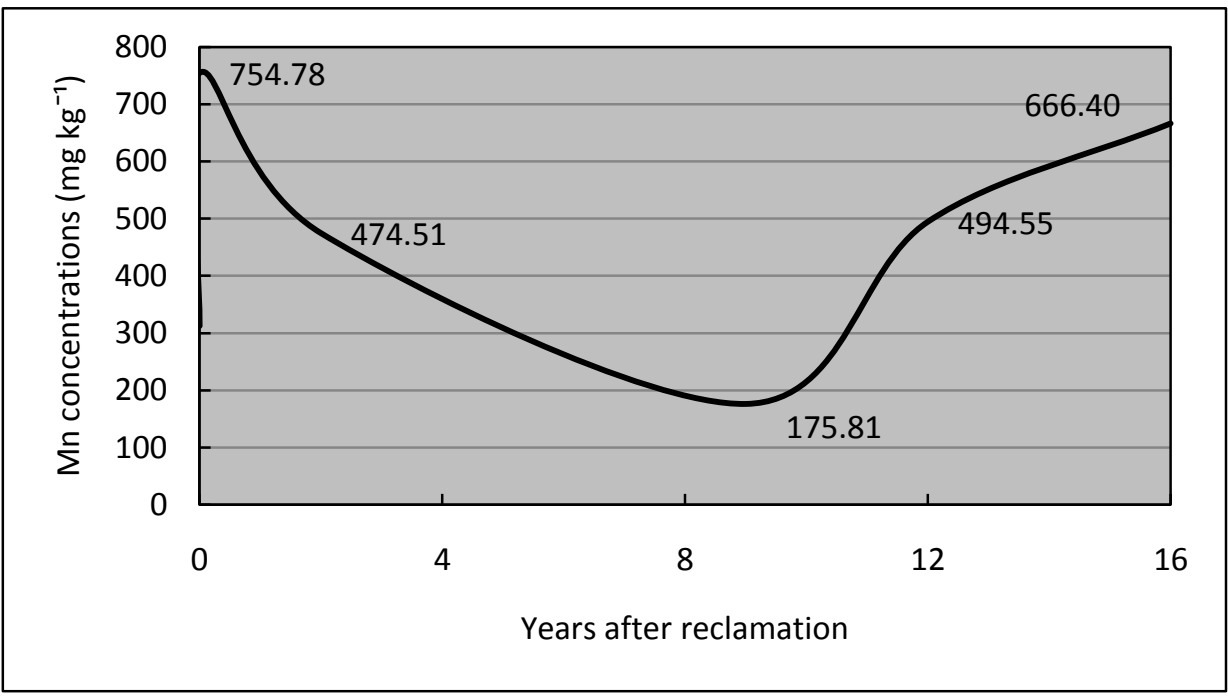

Figure 3. The dynamics of manganese concentrations in the various stages of reclamation.

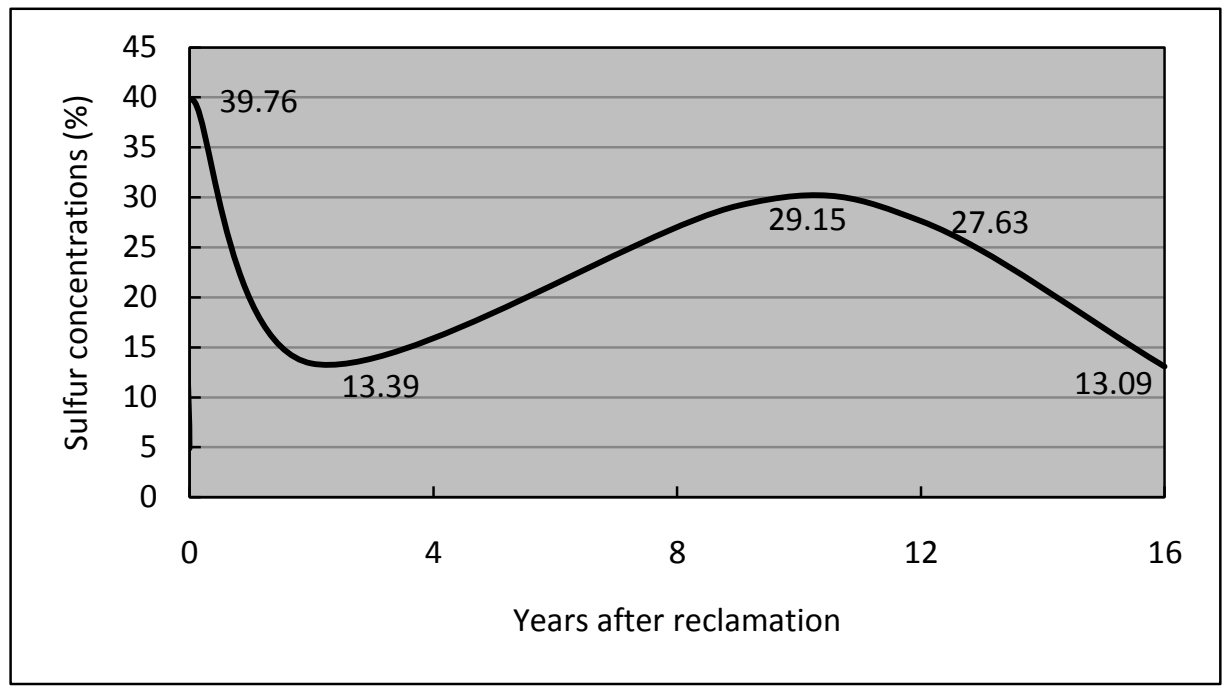

Figure 4. The dynamics of sulfur concentrations in the various stages of reclamation. 


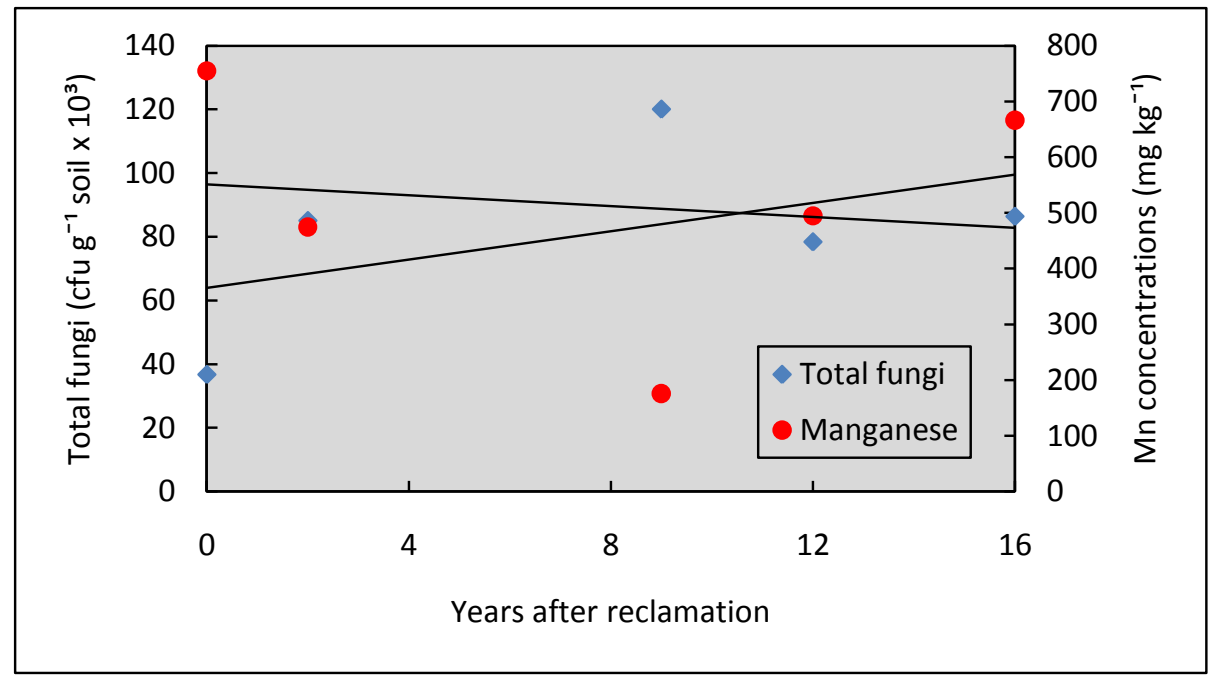

Figure 5. Relationship of soil fungi to the manganese concentrations.

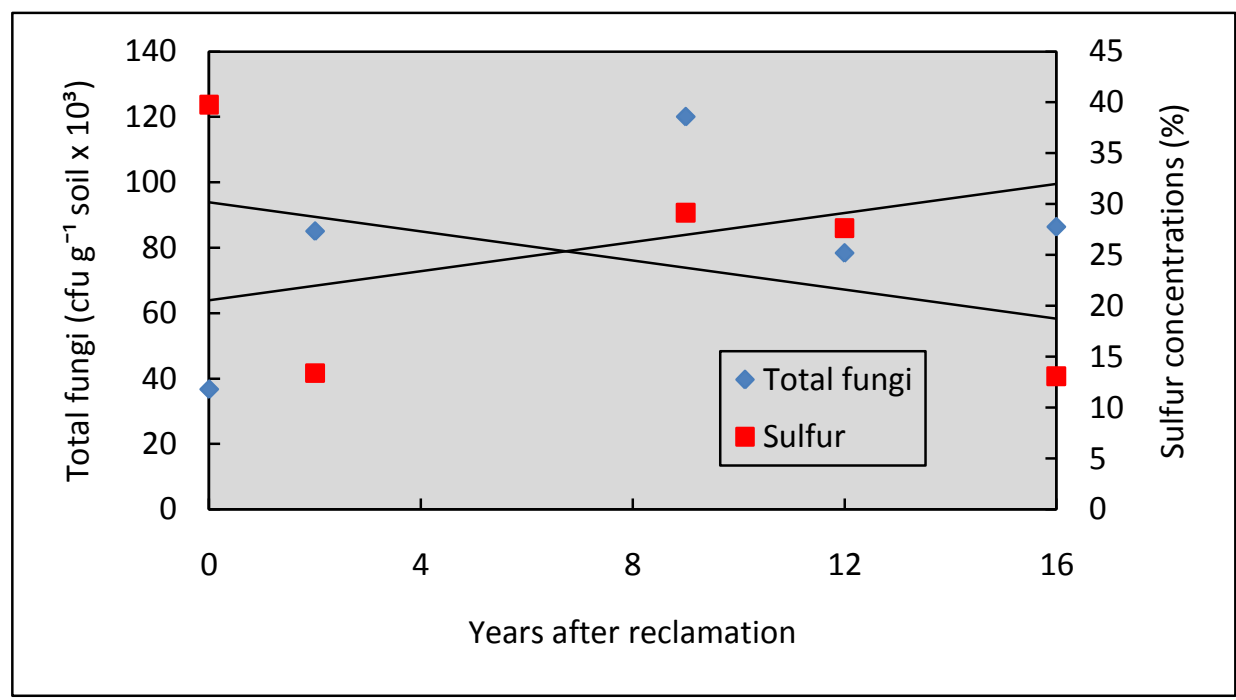

Figure 6. Relationship of soil fungi to the sulfur concentrations.

typically pyrite, and is characterized by low $\mathrm{pH}$ and high concentrations of $\mathrm{SO}^{2-}{ }^{2-}$ Fe, metalloids, and many metals.

\section{Interaction between soil fungi and manganese and sulfur concentrations}

In this study, the numbers of soil fungi were found negatively correlated with manganese concentrations (Figure 5). There is a tendency that the numbers of soil fungi affect the concentration of manganese. The higher numbers of soil fungi on the reclamation areas can cause a decrease in manganese concentrations.

A negative correlation found between the numbers of soil fungi and sulfur concentrations (Figure 6). The numbers of soil fungi increased initially, sulfur concentrations on the reclamation areas eventually decreased with time.
The reduction of manganese and sulfur concentrations observed in the soil could also be a cause of increased numbers of soil fungi. The slightly higher numbers of soil fungi in the reclamation areas can be attributed to lower manganese and sulfur concentrations. The results in agreement with the previous report of Arrieta and Grez (1971), Bratina et al. (1998), and Chaput et al. (2015) focused on the solubilization of ironcontaining minerals by soil microbes. There are several examples of fungi used for metal leaching. As described by White et al. (1997), the fungi can withstand a much wider $\mathrm{pH}$ range, and many can produce organic acids which can solubilize and complex metal cations. There are many fungi capable of producing organic acids, including Aspergillus niger (citric, oxalic, gluconic), Aspergillus spp. (citric, malic, tartaric, a- 
ketoglutaric, itaconic, aconitic), and Penicillium spp. (citric, tartaric, a-ketoglutaric, malic, gluconic). By altering parameters such as the $\mathrm{N}$ and $\mathrm{P}$ balance of the soil and optimum $\mathrm{pH}$, these species can be used to produce a wide range of organic acid for metal leaching purposes.

\section{Conclusion}

The results discussed here to show the numbers of soil fungi increased in the year after reclamation and then decreased after aging for nine years. The fungal groups that isolated were saprophytic fungi that present in a high relative density. The numbers of soil fungi found negatively correlated with manganese and sulfur concentrations in reclamation areas. The slightly higher numbers of soil fungi in the reclamation areas can be attributed to lower manganese and sulfur concentrations.

\section{ACKNOWLEDGEMENTS}

This research is a part of the first author's thesis for the master's degree at Mulawarman University. Many thanks to PT Kitadin for all the facilities during this research.

\section{REFERENCES}

Arrieta L and R Grez. 1971. Solubilization of iron-containing minerals by soil microorganisms. Appl. Microbiol. 22 (4): 487-490.

Barnett HL and BB Hunter. 1972. Illustrated Genera of Imperfect Fungi. $3^{\text {rd }}$ edition. Burgess Publishing Co. Minneapolis.

Bratina BJ, BS Stevenson, WJ Green and TM Schmidt. 1998. Manganese reduction by microbes from Oxic Regions of the Lake Vanda (Antartica) Water Column. Appl. Environ. Microbiol. 64 (10): 3791-3797.

Campaner VP, W Luiz-Silva and W Machado. 2014 Geochemistry of acid mine drainage from coal mining area and processes controlling metal attenuation in stream waters, southern Brazil. An. Acad. Bras. Cienc. 86 (2): 539554

Chaput DL, CM Hansel, WD Burgos and CM Santelli. 2015. Profiling microbial communities in manganese remediation systems treating coal mine drainage. Appl. Environ. Microbiol. 81 (6): 2189-2198.

Domsch KH, W Gams and T Anderson. 1980. Compendium of Soil Fungi. Academic Press. London.

Dutta M, J Saikia, SR Taffarel, FB Waanders, D de Medeiros, C Cutrueno, L Silva and BK Saikia. 2017. Environmental assesment and nano-mineralogical characterization of coal, overburden and sediment from Indian coal mining acid drainage. Geoscience Frontiers. 8: 1285-1297.

Fresquez PR, EF Aldon and WC Lindemann. 1987. Diversity and composition of soil fungi associated with reclaimed coal mine spoils and soils. Proceed. Am. Soc. Min. Recl. pp 107114.

Funfgeld A. 2016. The state of coal mining in East Kalimantan: towards a political ecology of local stateness. Austrian Journal of South-East Asian Studies. 9 (1) 147-162.

Garcia WM, BW Zago, JS da Silva Nunes dan IF de Carvalho. 2015. Diversity of filamentous fungi in Cerrado soil under native vegetation. Rev. Bras. Biocien. 13 (4): 245-249.

Gomez RP, MB Auliciano, Cl Monaco, N Kripelz and CA Cordo. 2016. Composition and dynamics of the fungal populations in a typical Phaeozem luvico in Argentina. Cogent Food and Agriculture. 2: 11-25.

Komara LL, DN Choesin and TS Syamsudin. 2016. Plant diversity after sixteen post coal mining in East Kalimantan, Indonesia. Biodiversitas. 17 (2): 531-538.

Kurakov AV, RB Lavrent'ev, TY Nechitailo, PN Golyshin and DG Zvyagintsev. 2008. Diversity of facultatively anaerobic microscopic mycelia fungi in soils. Microbiology. 77 (1): 9098.

Marganingrum D and R Noviardi. 2010. Water and soil pollution in the coal mining area at PT Berau Coal, Kalimantan Timur. Riset Geologi dan Pertambangan. 20 (1): 11-20. [Indonesian]

Meliani A, A Bensoltane and K Mederbel. 2012. Microbial diversity and abundance in soil: related to plant soil type. Am. J. Plant Nutr. Fert. Technol. 2 (1): 10-18.

Mulyana D. 2009. Soil quality at several area cover post revegetation (case study post revegetation at Ciliwung uper watershed). Thesis. Institut Pertanian Bogor. Bogor. [Indonesian]

Mummey DL, PD Stahl and JS Buyer. 2002. Soil microbiological properties 20 years after surface mine reclamation: spatial analysis of reclaimed and undisturbed sites. 34: 1717-1725.

Qin Fan-xin, Wei Chao-fu, Zhong Shou-qin, Huang Xian-fei, Pang Wen-pin and Jiang Xin. 2016. Soil heavy metal(loid)s and risk assessment in vicinity of coal mining area from southwest Guizhou, China. J. Cent. South Univ. 23: 22052213.

Rousk J, PC Brookes and E Baath. 2009. Contrasting soil pH effects on fungal and bacterial growth suggest functional redundancy in carbon mineralization. Appl. Environ. Microb. 75 (6): 1589-1596.

Roy-Bolduc A, E Laliberte, S Boudreau and M Hijri. Strong linkage between plant and soil fungal communities along successional coastal dune system. FEMS Microbiol. Ecol. 92 (10): 1-10.

Sahoo PK, SK Equeenuddin and MA Powell. 2016. Trace elements in soils around coal mines: current scenario, impact and available techniques for management. Curr Pollution Rep. 2: 1-14. 
Agroradix Vol. 2 No.2 Juni (2019)

Silva L, X Querol, KM da Boit, S de Vallejuelo and JM Madariaga. 2011. Brazilian coal mining residues and sulphide oxidation by Fenton's reaction: an accelerated weathering procedure to evaluate possible environmental impact. J. Hazardous Materials. 186: 516-525.

Suciatmih. 2006. Soil mycoflora of banana and cassava in peatland and alluvial soil in Bengkulu. Biodiversitas. 7 (4): 303-306. [Indonesian]

White C, JA Sayer and GM Gadd. 1997. Microbial solubilization and immobilization of toxic metals: key biogeochemical processes for treatment of contamination. FEMS Microbiol. Rev. 20: 503-516.

Wong MH. 2003. Ecological restoration of mine degraded soils, with emphasis on metal contaminated soils. Chemosphere. 50: 775-780.

Yusuf $\mathrm{M}$ and $\mathrm{E}$ Arisoesilaningsih. 2017. Exotic plants species attack revegetation plants in post-coal mining areas. $8^{\text {th }}$ International Conference on Global Resource Conservation 2017. Kuala Lumpur. 